\title{
Breeding sex ratios in two declining diving duck species: between-year variation and changes over six decades
}

\author{
Hannu Pöysä ${ }^{1}$ D $\cdot$ Pentti Linkola ${ }^{2}$ - Antti Paasivaara ${ }^{3}$
}

Received: 21 January 2019 / Revised: 26 March 2019 / Accepted: 31 May 2019 / Published online: 10 June 2019

(c) The Author(s) 2019

\begin{abstract}
Sex ratio variation has important consequences for population dynamics and viability. Adult sex ratio is male biased in many duck species, and data from wintering areas suggest male bias has been increasing in some European duck species. However, the reasons for changes in sex ratios remain poorly understood, and information on sex ratio variation among breeding ducks is limited. We studied long-term changes in breeding sex ratios and breeding numbers in Common Pochard Aythya ferina and Tufted Duck Aythya fuligula in southern Finland, the former species being currently assessed as critically endangered and the latter as endangered in Finland. In addition, we tested the hypothesis that between-year variation in breeding sex ratios is affected by the severity of weather conditions in the wintering areas. The proportion of females among breeding Tufted Ducks decreased from $42.9 \%$ in 1951-1970 to $36.9 \%$ in 1996-2015, while no statistically significant change was observed in Common Pochard (41.8\% and 39.5\%, respectively). Both species showed a decline in breeding numbers over the same period. Severity of the preceding winter did not affect the proportion of females in the breeding area.
\end{abstract}

Keywords Adult sex ratio $\cdot$ Aythya ferina $\cdot$ Aythya fuligula $\cdot$ Breeding population $\cdot$ Threatened species $\cdot$ Winter severity

\section{Zusammenfassung}

Geschlechterverhältnis zur Brutzeit bei zwei im Bestand abnehmenden Tauchentenarten: Variation zwischen den Jahren und Veränderungen über sechs Jahrzehnte

Die Variation bezüglich des Geschlechterverhältnisses hat wichtige Konsequenzen für die Dynamik und Lebensfähigkeit von Populationen. Bei vielen Entenarten ist das Geschlechterverhältnis bei den Adulten zugunsten der Männchen verschoben, und Daten aus den Überwinterungsgebieten deuten darauf hin, dass diese „Männchenlastigkeit“ bei manchen europäischen Entenarten zugenommen hat. Allerdings sind die den Änderungen im Geschlechterverhältnis zugrundeliegenden Ursachen bislang kaum erforscht und Informationen zur Geschlechterverhältnis-Variation bei Enten zur Brutzeit nur begrenzt verfügbar. Wir untersuchten langfristige Veränderungen des Geschlechterverhältnisses zur Brutzeit sowie der Brutvogelzahlen bei Tafelente Aythya ferina und Reiherente Aythya fuligula in Südfinnland; die erste Art wird in Finnland derzeit als „,vom Aussterben bedroht“, die letztere als „stark gefährdet“ eingestuft. Zusätzlich überprüften wir die Hypothese, dass die jahresweise Variation des Geschlechterverhältnisses zur Brutzeit von der Härte der Wetterbedingungen in den

Communicated by C. Barbraud.

Electronic supplementary material The online version of this article (https://doi.org/10.1007/s10336-019-01682-7) contains supplementary material, which is available to authorized users.

Hannu Pöysä

hannu.poysa@luke.fi

1 Natural Resources, Natural Resources Institute Finland (Luke), Yliopistokatu 6, 80100 Joensuu, Finland

2 Lehtimäentie 176, 37720 Ritvala, Finland

3 Natural Resources, Natural Resources Institute Finland (Luke), Paavo Havaksen tie 3, 90570 Oulu, Finland 
Überwinterungsgebieten beeinflusst wird. Der Weibchenanteil bei brütenden Reiherenten ging von 42,9\% zwischen 19511970 auf 36,9\% zwischen 1966-2015 zurück, wohingegen bei der Tafelente keine statistisch signifikante Änderung beobachtet wurde (41,8\% beziehungsweise 39,5\%). Beide Arten zeigten über denselben Zeitraum hinweg abnehmende Brutvogelzahlen. Die Strenge des vorangegangenen Winters hatte keinen Einfluss auf den Weibchenanteil im Brutgebiet.

\section{Introduction}

Sex ratio variation has important consequences for population dynamics and viability. For example, theoretical work has shown that, in species with a purely monogamous mating system, demographic stochasticity may cause a shortage of males and reduce population growth rate, possibly increasing extinction risk due to an Allee effect (Engen et al. 2003). In general, both mating system and sex ratio affect the demographic variance, dynamics and extinction risk of populations (Lee et al. 2011). Considering conservation implications of biased adult sex ratios for birds in general, male bias has been shown to be associated with the threatened status of species (Donald 2007). Clearly, we should increase our understanding of the variation of adult sex ratios in bird populations, in particular for declining species.

Male-biased sex ratios were documented for many duck species several decades ago both in Europe and North America (Linkola 1960; Bellrose et al. 1961; Hildén 1964). While variation of sex ratios of European ducks during the non-breeding season has been studied extensively (e.g. Nilsson 1970; Owen and Dix 1986; Carbone and Owen 1995; Brides et al. 2017; Fox and Christensen 2018), research on sex ratio variation among breeding ducks is limited. Because staging and wintering areas gather birds from different parts of the breeding range, and the origin of birds usually remains unknown, data from wintering areas are not well suited to the study of specific mechanisms behind changes in sex ratios. Lehikoinen et al. (2008) and Ramula et al. (2018) studied possible mechanisms that could lead to male-biased adult sex ratios in Common Eiders Somateria mollissima, a seasonally monogamous sea duck. Ramula et al. (2018) concluded that, although duckling mortality is female biased and could contribute to male-dominated adult sex ratios (Lehikoinen et al. 2008), the most probable explanation of male-biased adult sex ratio in their study populations (central and western Gulf of Finland) is lower survival of females than males among experienced breeders, most likely due to increased predation pressure on incubating females. Similarly, Bellebaum and Mädlow (2015) found in an introduced Mandarin Duck Aix galericulata population in two German cities (Berlin and Potsdam) that higher mortality of females than males in particular during the breeding season can explain male-biased adult sex ratio. Lower survival of females than males in the breeding season has also been documented for Common Teal Anas crecca ringed in the Camargue, southern France (Devineau et al. 2010).
In general, current knowledge suggests that adult sex ratios in wild bird populations are better explained by sex-biased adult mortality rates rather than by hatching or juvenile sex ratios (Donald 2007; Székely et al. 2014).

Here, we use historical (1951-1970) and recent (1996-2015) data from a study area in southern Finland to study long-term changes and between-year variation of sex ratios in breeding Common Pochard Aythya ferina and Tufted Duck Aythya fuligula. Both species are seasonally monogamous, like most duck species in the Northern Hemisphere (Oring and Sayler 1992). In Linkola's (1960) data from the same area for 1950-1956 the breeding sex ratio (males to females) was 1.38 for the Common Pochard and 1.28 for the Tufted Duck. Samples of hunter-shot birds from Denmark indicate that the proportion of females amongst adult Tufted Ducks increased from 1982 to 2017 (Fox and Christensen 2018) but not in the Common Pochard from 1982 to 2010 (Christensen and Fox 2014). Adult sex ratios among the hunter-shot birds from Denmark also indicate considerable between-year variation for both species (see Christensen and Fox 2014; Fox and Christensen 2018) but factors affecting the variation have not been studied. As recently found in the Common Eider and Mandarin Duck (see above), lower survival of females during the breeding season may contribute to male-biased sex ratios, this being one of the earliest hypotheses put forward to explain malebiased sex ratios in waterfowl (Bellrose et al. 1961). However, less attention has been paid to the possibility that sex differences in over-winter survival can affect sex ratios of breeding birds, although lower survival of females during periods of harsh winter has been identified as a plausible hypothesis in this context (e.g. Nichols and Haramis 1980). This hypothesis is particularly relevant to Common Pochard and Tufted Duck. First, both species respond to harsh wintering conditions by moving to more benign areas with open water (Ridgill and Fox 1990; Keller et al. 2009; GourlayLarour et al. 2012). Even though movements obviously are advantageous in terms of avoiding mortality due to cold weather, such weather-induced movements per se may cause extra mortality; moving farther south might also increase hunting mortality because hunting pressure there is assumed to be higher (e.g. Brides et al. 2017). Mass mortality due to an extreme cold spell has been documented for both species (Suter and Van Eerden 1992). Furthermore, sex differences in wintering areas [females wintering in more southern areas than males (e.g. Carbone and Owen 1995)] have been attributed to differences in competitive ability between the 
sexes, females being the less competitive sex (e.g. Nichols and Haramis 1980; Choudhury and Black 1991; Carbone and Owen 1995). Winter severity affects female survival in the Common Pochard (Blums et al. 2002, 2005). On the other hand, Gourlay-Larour et al. (2013a, b) did not find sex differences in winter survival rates of Common Pochard at a wintering site in western France. Unfortunately, ringing data of Common Pochard and Tufted Duck males are insufficient for analysing sex differences in survival in northern wintering areas.

We formulated two study questions, based on earlier hypotheses and on previous findings from wintering areas, to explain male-biased sex ratios in waterfowl. First, do the breeding sex ratios of the two diving duck species show any changes between 1951-1970 and 1996-2015? Second, to address the possible impact of winter conditions on breeding sex ratios, we ask whether the proportion of females in the breeding population decreases with increasing severity of the preceding winter. Finally, we study whether the breeding numbers of the Common Pochard and Tufted Duck in our study area decreased between 1951-1970 and 1996-2015.

\section{Methods}

\section{Data on sex ratios and breeding numbers}

The senior author (P. L.) of this study gathered all the data at 25 lakes in central Häme, southern Finland, from 1951 to 1970 and from 1996 to 2015, using the same field methods in all years. In 1971-1995 censuses were done only occasionally and at a few lakes; hence data for this period were insufficient for analyses. All the study lakes are within an area of ca. $45 \times 55 \mathrm{~km}$ (central coordinate $61^{\circ} 12^{\prime} \mathrm{N}, 24^{\circ} 18^{\prime} \mathrm{E}$; for characterization of the study lakes, see Online Resource Table A1). Small lakes were surveyed from vantage points (in some cases from a tree or a bird-watching tower) or by walking around the lake. Large lakes were surveyed by rowing in a boat near the shoreline to cover all open water areas. Because individual birds, pairs and groups of Common Pochard and Tufted Ducks usually stay on the open water and are highly visible, they are easy to count in April and May before the vegetation has started to grow. P. L.'s original idea was to develop a standardized duck survey method in which species differences in sex ratios and withinseason changes in sex ratios are taken into account (Linkola $1959,1960)$. Hence, the numbers of males and females were recorded for both species on each visit to a lake between the end of April and the end of May. For this study, we considered only surveys (visits) that covered the whole lake, i.e. the numbers presented here concern the whole breeding population of a lake. We only included the first non-zero observation of each species from a given lake and year (see also below). To take into account the differences in speciesspecific optimal census times of breeding birds (Linkola 1959; Kauppinen 1983; Pöysä 1996), and to minimize the risk that females were at the nest and therefore not visible during the survey, we only accepted the first observation if it was done before 16 May for the Common Pochard and before 26 May for the Tufted Duck (Tufted Duck females start egg-laying later than Common Pochard females; for additional information on the sex ratio data and the timing of bird censuses, see Online Resource Appendix A1, Fig. A1 and Table A2). Hence, the observations can also be used to estimate local breeding numbers. If no individuals were recorded at any visit within the acceptable time window for a given species, the breeding number in that year was set to zero (i.e. the 'first observation' equals zero). Because Common Pochard and Tufted Ducks did not necessarily occur on the same lakes, and the species-specific acceptable time window was not necessarily met for a given lake in any year in 1951-1970 or 1996-2015, final sample sizes in the analyses concerning breeding numbers are less than 25 lakes and differ between the species. Mean numbers of years per lake were as follows: Common Pochard-1951-1970, mean $=4.1$ $(\mathrm{SD}=3.6$, range 1-13); 1996-2015, mean $=10.8(\mathrm{SD}=5.9$, range 1-19); Tufted Duck-1951-1970, mean $=4.8$ $(\mathrm{SD}=3.5$, range 1-13); 1996-2015, mean $=10.9(\mathrm{SD}=5.9$, range 1-19).

\section{Winter severity data}

We selected 12 weather stations in western and southern Europe (see Online Resource: Table A3) to represent typical wintering areas of the species; winter-time ring recoveries of Common Pochard and Tufted Ducks ringed in Finland (Saurola et al. 2013) confirm that these areas are relevant also for birds breeding in Finland. For these stations, we downloaded the mean daily temperatures for December, January and February 1951-1970 and 1996-2015 from http://www.ecad.eu (Klein Tank et al. 2002) and calculated the Hellman index (Hellmann 1918) as the sum of mean daily temperatures that were below zero between 1 December and 28 February [winter severity index (WSI); note that absolute values were used]. This index has been found to be useful when studying effects of harsh wintering conditions on movements of ducks, including Common Pochard and Tufted Duck, in Europe (Ridgill and Fox 1990; Keller et al. 2009; Gourlay-Larour et al. 2012). To take into account differences between the species and sexes in wintering areas (Owen and Dix 1986; Carbone and Owen 1995; Saurola et al. 2013), we calculated WSI separately for northern wintering areas (mean of the WSIs of the six stations representing the northern areas; Online Resource Table A3, Fig. A2) and southern wintering areas (mean of the WSIs of the six stations representing the southern areas; Online Resource 
Table A3, Fig. A2). Note that the classification of stations to represent a 'northern' or a 'southern' wintering area also followed the maritime-continental (west-east) gradient (see Ridgill and Fox 1990) and not only the north-south gradient.

\section{Statistical analyses}

We used generalized linear mixed models (GLMMs) with a binomial error distribution to study if there was a difference in the proportion of females between 1951-1970 and 1996-2015, and whether inter-annual variation in the proportion of females was associated with the severity of the preceding winter (WSI). Because WSIs were strongly correlated between northern and southern areas $(r=0.889$, $d f=38, p<0.001$; based on data depicted in Online Resource Fig. A2), we ran two separate models (period + WSI north and period + WSI south) for both species. Lake and year were included as random effects in both models, and standardized WSIs were used in the analyses. Finally, we used GLMMs with a Poisson error distribution to study if the numbers of females and males changed between 1951-1970 and 1996-2015. Lake and year were included as random effects in all models. In these analyses, and for both species, we included all lakes for which we had data from the acceptable time window of the first observation (same criteria as with the sex ratio data, see above) for both periods.

All statistical analyses were performed in $\mathrm{R}$ (version $\mathrm{R}$ 3.4.1; R Core Team 2017) using the lme 4 package and glmer function.

\section{Results}

In the Tufted Duck, the proportion of females in the breeding population decreased from $42.9 \%$ ( $n=1474$ individuals) in 1951-1970 to $36.9 \%(n=534)$ in 1996-2015, while no statistically significant change was observed in the Common Pochard [41.8\% females $(n=914)$ in $1951-1970$ and 39.5\% $(n=569)$ in 1996-2015; Table 1]. The proportion of females varied considerably between years in both species (Fig. 1), as did the WSI (Online Resource Fig. A2). However, we did not find an impact of the severity of the preceding winter on the proportion of females in the breeding population for either species (Table 1).

The numbers of females and males decreased between 1951-1970 and 1996-2015 in both species (Fig. 2; Table 2). In both species, the decrease seemed to be particularly strong on lakes that had the highest breeding numbers in 1951-1970, and the few compensatory changes (i.e. increases) were minimal, the changes together meaning drastic overall population declines (see Fig. 2).
Table 1 Generalized linear mixed models (GLMMs) for changes in the proportion of females between 1951-1970 and 1996-2015 (period) and for the impact of the severity of the preceding winter in northern (WSI north) and southern (WSI south) wintering areas on the proportion of females among breeding Common Pochard and Tufted Ducks

\begin{tabular}{|c|c|c|c|c|}
\hline & $\beta$ & SE & $z$ & $p$ \\
\hline \multicolumn{5}{|c|}{ Common Pochard ( $n=291$ lake-year cases) } \\
\hline \multicolumn{5}{|l|}{ Model 1} \\
\hline Period & -0.142 & 0.114 & -1.237 & 0.216 \\
\hline WSI north & -0.062 & 0.046 & -1.352 & 0.176 \\
\hline \multicolumn{5}{|l|}{ Model 2} \\
\hline Period & -0.127 & 0.113 & -1.117 & 0.264 \\
\hline WSI south & -0.042 & 0.040 & -1.053 & 0.292 \\
\hline \multicolumn{5}{|c|}{ Tufted Duck ( $n=329$ lake-year cases) } \\
\hline \multicolumn{5}{|l|}{ Model 1} \\
\hline Period & -0.267 & 0.108 & -2.467 & 0.014 \\
\hline WSI north & -0.019 & 0.034 & -0.568 & 0.570 \\
\hline \multicolumn{5}{|l|}{ Model 2} \\
\hline Period & -0.264 & 0.107 & -2.459 & 0.014 \\
\hline WSI south & -0.015 & 0.029 & -0.523 & 0.601 \\
\hline
\end{tabular}

Because WSI north and WSI south were correlated (see "Methods", "Statistical analyses"), they were considered in separate models (models 1 and 2). Lake and year were included as random effects in all models

\section{Discussion}

We found that the proportion of females among breeding birds decreased between 1951-1970 and 1996-2015 in the Tufted Duck but not in the Common Pochard, both species showing a strong decline in breeding numbers over the same period. Contrary to our prediction, the proportion of females at the beginning of the breeding season was not negatively associated with the severity of the preceding winter.

Lower survival of females during the breeding season is one of the earliest hypotheses put forward to explain male-biased sex ratios in waterfowl (Bellrose et al. 1961). The question then arises: has breeding season mortality of females increased between 1951-1970 and 1996-2015? Two of the most important alien predators of nesting duck females, viz. the American Mink Mustela vison and Raccoon Dog Nyctereutes procyonoides (e.g. Blums et al. 2003; Viksne et al. 2011; Fox et al. 2016) did not occur in our study area in 1951-1970 (P. Linkola, personal observation). These predators were rare also elsewhere in Finland at that time, but have dramatically increased in numbers since the 1950s and 1960s (Helle and Kauhala 1991; Kauhala 1996). This is also the case with the Marsh Harrier Circus aeruginosus (Hyytiä et al. 1983; Valkama et al. 2011), an avian predator that is known to catch at least Common Pochard females (Blums et al. 2003; Viksne et al. 2011). Hence, an apparent increase in predation pressure between 1951-1970 
0,6 (a)

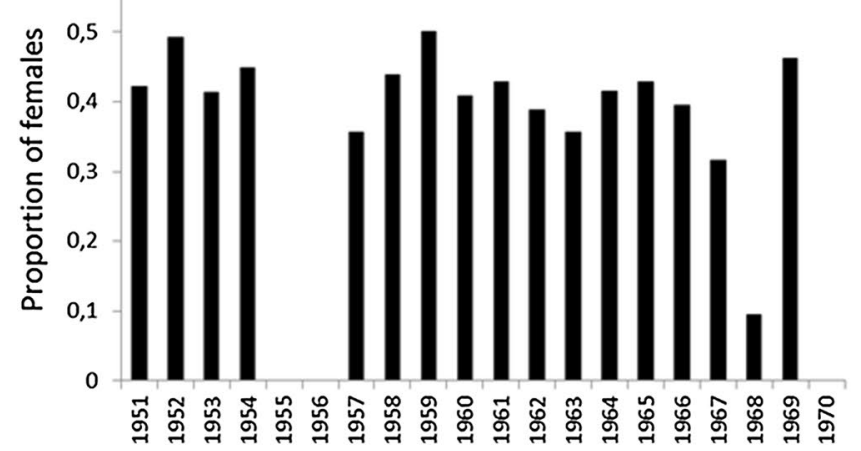

$0,6>$ (c)

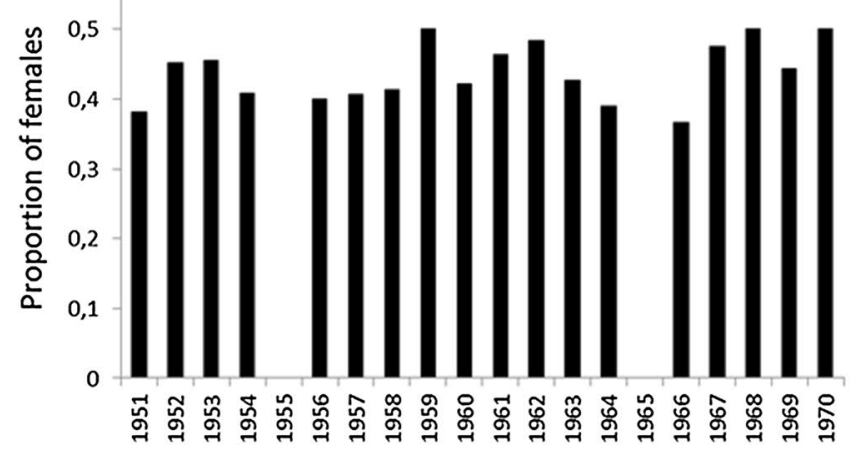

0,6

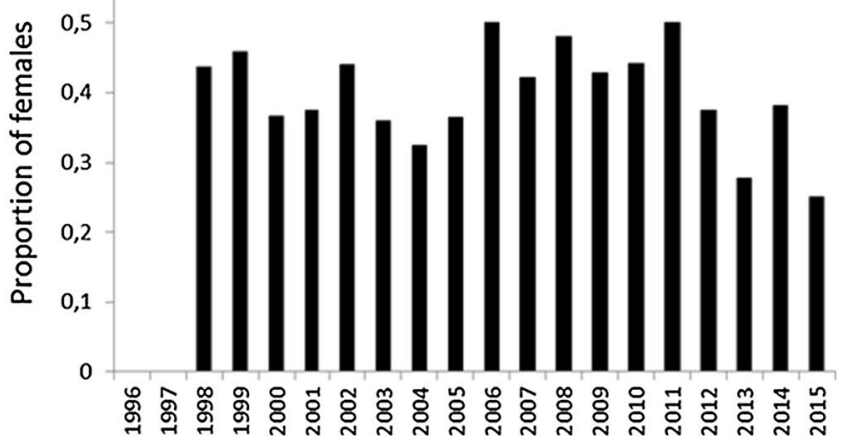

$0,6\urcorner(d)$

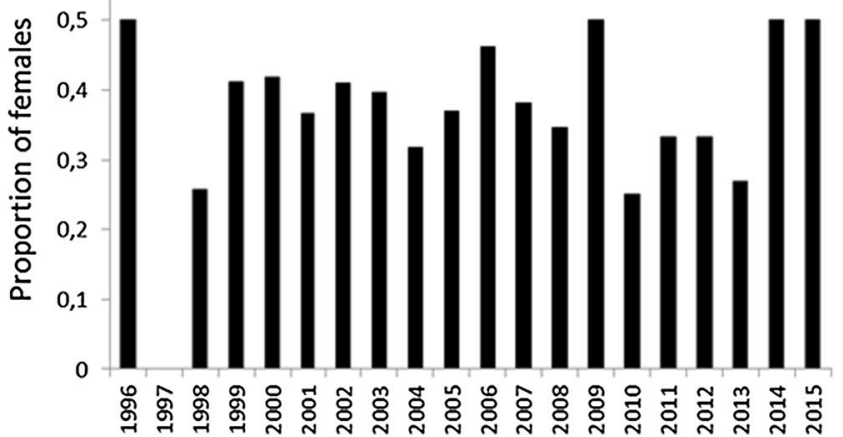

Fig. 1 Proportion of females among breeding Common Pochard (a, b) and Tufted Ducks (c, d) in 1951-1970 (left panels) and 1996-2015 (right panels) in annual data pooled over all lakes

and 1996-2015 could explain the long-term decline in the proportion of Tufted Duck females. However, that a corresponding decline was not found in the Common Pochard does not agree with the predation hypothesis, and other factors than female-biased predation must be involved. These other factors may be related to the phenomenon that winters across northern wintering areas have become milder (Lehikoinen et al. 2013), which in turn may have affected the winter distribution of Common Pochard females in Europe. Interestingly, Brides et al. (2017) found that countries at lower latitudes (e.g. France and Spain) were more likely to show an increased male bias in the sex ratio in 2016 compared with 1989-1990, whereas more northerly countries showed little or no change. A higher proportion of Common Pochard females may nowadays winter in more northern areas, thereby avoiding high hunting pressure of the southern wintering areas [for national bag statistics see Hirschfeld and Heyd (2005) and Guillemain et al. (2016); see also Brides et al. (2017)]. Furthermore, exposure to lead poisoning from gunshot ingestion is higher in southern than northern Europe (Mateo 2009). It has been suggested that because Common Pochard females tend to winter further south than males, mortality due to lead poisoning has been higher in Common Pochard females than in males (Green and Pain 2016). A possible decrease in mortality due to hunting and lead poisoning could have compensated for a possible increase in breeding season mortality in Common Pochard females. Finally, difference in the timing of breeding between Common Pochard (early nester) and Tufted Duck (late nester) females may have differently exposed them to possible changes in predation pressure due to climate warming (earlier spring thaw), late-nesting duck species being probably more vulnerable to climate-driven phenological mismatches than early nesting species (see Drever and Clark 2007; Drever et al. 2012).

Our results contradict those of Christensen and Fox (2014) who found that the proportion of adult females among samples of hunter-shot birds from Denmark increased for the Tufted Duck (see also Fox and Christensen 2018) and decreased, although not significantly, for the Common Pochard in 1982-2010. Brides et al. (2017) also found that the proportion of Common Pochard females in the International Waterbird Census, done in mid-winter in Europe and North Africa, decreased from 1989-1990 to 2016. Frew et al. (2018) found a similar trend in the proportion of Common Pochard females at a wintering site in northwest England in the winters of 1991/1992 until 2005/2006, but no trend for Tufted Duck.

These contradictory findings from breeding and wintering areas are difficult to explain, given the paucity of 

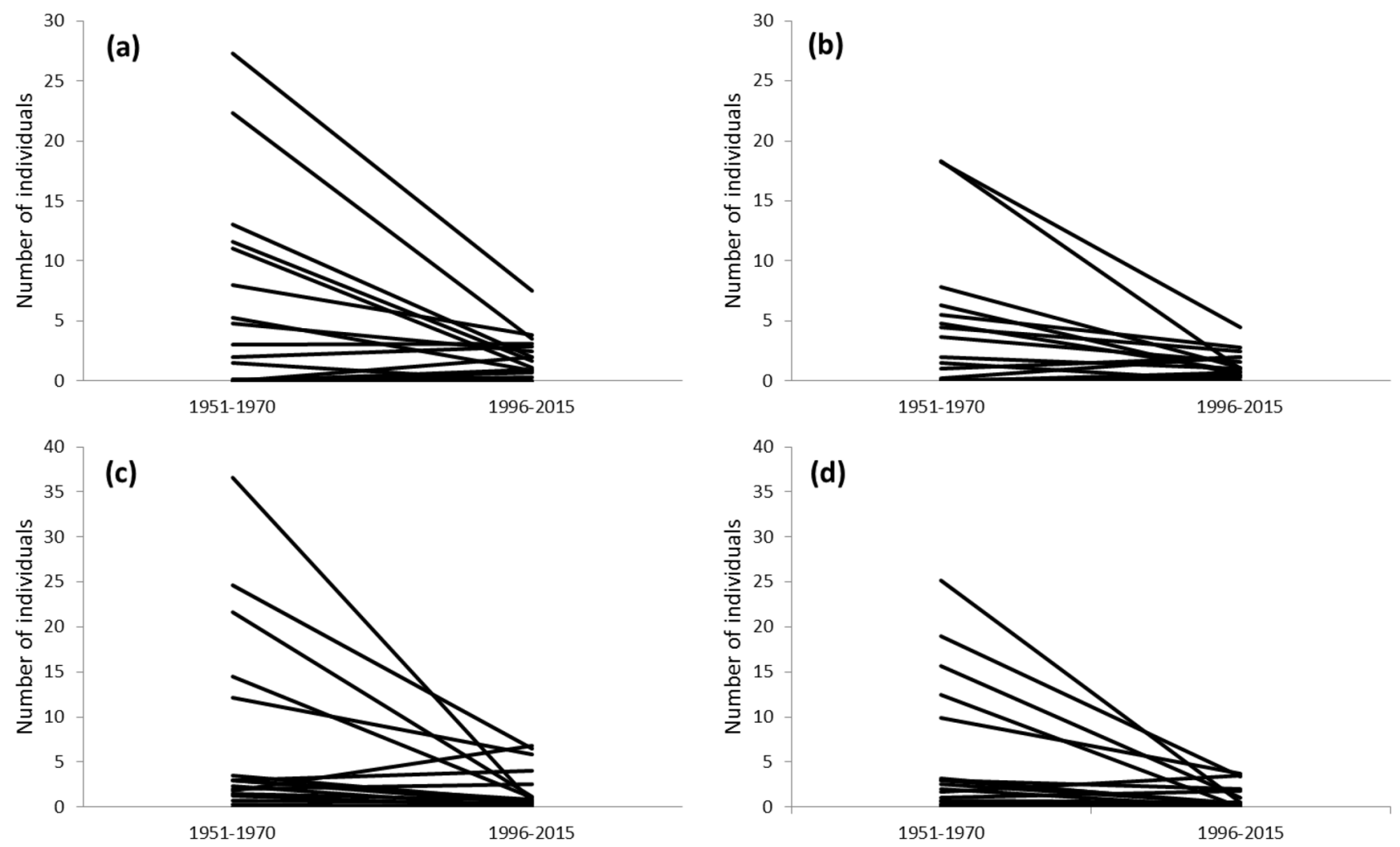

Fig. 2 Lake-specific changes in the mean number of Common Pochard ( $n=18$ lakes) males (a) and females (b) and Tufted Duck ( $n=19$ lakes) males (c) and females (d) between 1951-1970 and 1996-2015

Table 2 GLMMs for changes in the numbers of females and males between 1951-1970 and 1996-2015 for Common Pochard and Tufted Duck

\begin{tabular}{|c|c|c|c|c|}
\hline & $\beta$ & $\mathrm{SE}$ & $z$ & $p$ \\
\hline \multicolumn{5}{|c|}{ Common Pochard ( $n=291$ lake-year cases) } \\
\hline Females & -1.233 & 0.161 & -7.651 & 0.000 \\
\hline Males & -1.211 & 0.133 & -9.114 & 0.000 \\
\hline \multicolumn{5}{|c|}{$\begin{array}{l}\text { Tufted Duck ( } n=329 \\
\text { lake-year cases) }\end{array}$} \\
\hline Females & -1.746 & 0.180 & -9.731 & 0.000 \\
\hline Males & -1.507 & 0.208 & -7.258 & 0.000 \\
\hline
\end{tabular}

Lake and year were used as random effects in all models

research on factors affecting variation in sex ratios in these and other duck species. Fox and Christensen (2018) discussed potential problems associated with measuring sex ratios from hunter-shot birds, and Brides et al. (2017) discussed corresponding problems with mid-winter waterbird counts. In general, concerning data from wintering areas, be it hunter-shot birds or field counts, sex and between-year differences in migration, wintering areas and weather-induced movements, coupled with climate change-driven long-term changes in these (e.g. Lehikoinen et al. 2013), make reliable estimation of sex ratios challenging. As for breeding populations, Common Pochard and Tufted Duck females are highly philopatric to their breeding sites (Blums et al. 2002), as is the case for waterfowl in general (Anderson et al. 1992). In addition, Blums et al. (2003) found on Engure Marsh, Latvia, that nest success did not affect breeding dispersal (from year $t$ to year $t+1$ ) of individual females of either species, the mean breeding dispersal distances (successful and failed nests combined) being ca. $240 \mathrm{~m}$ in the Common Pochard and ca. $217 \mathrm{~m}$ in the Tufted Duck. Hence, mortality and decreased recruitment presumably are the main drivers of change in female numbers in the breeding lakes, although permanent emigration cannot be totally ruled out. Very little is known about the breeding site fidelity of Common Pochard and Tufted Duck males, but for ducks in general breeding site fidelity is considered to be lower in males than in females (Anderson et al. 1992). In line with this, Gourlay-Larour et al. (2014) found that, in a wetland area in Western France, where wintering birds include both local breeders and winter visitors, breeding site fidelity of Common Pochard was lower for males than for females. Given that breeding dispersal of females in both species is rather limited even after a failed nest (see above), we do not see why the degree of breeding site philopatry should have changed differently in males and females, possibly affecting long-term changes in breeding sex ratios. All in all, given the 
contradictory findings from breeding and wintering areas, we urgently need more research on duck sex ratios from different parts of their breeding and wintering ranges, and on factors that affect between-year variation in sex ratios and probably drive their long-term changes. In particular, ringing effort of not only these species but ducks in general should be increased both in the breeding and wintering areas in order to better understand sex ratio bias and differences in survival between males and females.

We did not find support for the idea that winter severity per se affects breeding sex ratios in Common Pochard and Tufted Duck. This was surprising because earlier studies have demonstrated clear effects of wintering conditions on the movement and distribution of Common Pochard and Tufted Duck, and even effects on female mortality (references in "Introduction"). The severity of winters varied considerably between years, in particular in the northern wintering areas (see Online Resource Fig. A2), meaning that a lack of response was probably not due to limited environmental variation in our data.

That the proportion of Tufted Duck females showed a long-term decline is alarming, in particular because also the breeding numbers of the species in Finland have been decreasing (Pöysä et al. 2013; Lehikoinen et al. 2016; this study), to the extent that the conservation status of the species in Finland is currently considered as endangered (Lehikoinen et al. 2019). These findings are worrying, considering that adult sex ratios have been found to be more heavily male-biased in populations of globally threatened bird species than in non-threatened species (Donald 2007). The Common Pochard has shown rapid declines in breeding numbers across much of its breeding territory in Europe (Fox et al. 2016; Folliot et al. 2018), and is currently globally assessed as vulnerable (BirdLife International 2018) and critically endangered in Finland (Lehikoinen et al. 2019). The decrease in the proportion of Common Pochard females in the wintering areas, and its presumed association with increased mortality of females compared with males, has been coupled with the overall decrease of Common Pochard in Europe (e.g. Brides et al. 2017). A similar link has been suggested for changes in sex ratios and population declines in many other duck species in Europe (Fox and Christensen 2018). A male-biased sex ratio per se may not affect population growth rate and dynamics because, given the surplus of males, female reproduction should not be limited by male availability. However, a surplus of males can decrease the reproductive success of females and even increase female mortality due to pursuit flights and forced extra-pair copulations, which are frequent in waterfowl (McKinney et al. 1983). The reasons for the decline of Common Pochard and Tufted Duck breeding numbers are not known, but increased nest predation, changes in habitat quality and increased food competition between ducks and cyprinid fish are among those suggested (e.g. Pöysä et al. 2013; Fox et al. 2016; Lehikoinen et al. 2016). In addition, a recent study indicates that the loss of Black-headed Gull Chroicocephalus ridibundus colonies, which provide protection against nest predators, has contributed to the decline of Common Pochard and Tufted Duck breeding numbers in Finland (Pöysä et al. 2019).

In conclusion, the proportion of Tufted Duck females decreased between 1951-1970 and 1996-2015, and it is possible that increased predation pressure on nesting females contributed to this decrease. However, the fact that the breeding sex ratio of Common Pochard did not show a corresponding long-term change does not support the predation hypothesis. This suggests that there are other mortality factors that have affected Common Pochard and Tufted Duck females differently in the long term; these may be related to possible changes in the winter distribution of females due to decreasing winter severity in the northern wintering areas. However, our results do not support the idea that winter severity per se (i.e. causing extra mortality in females) is an important factor that can explain between-year variation and long-term changes of breeding sex ratios in Common Pochard and Tufted Duck. Understanding the causes and consequences of sex ratio bias and its variation in ducks and other birds, in particular for declining species, remains a primary challenge for further studies.

Acknowledgements Open access funding provided by Natural Resources Institute Finland (LUKE). We thank A. Fox, M. Guillemain and two anonymous referees for useful comments on an earlier draft of the manuscript.

Open Access This article is distributed under the terms of the Creative Commons Attribution 4.0 International License (http://creativeco mmons.org/licenses/by/4.0/), which permits unrestricted use, distribution, and reproduction in any medium, provided you give appropriate credit to the original author(s) and the source, provide a link to the Creative Commons license, and indicate if changes were made.

\section{References}

Anderson MG, Rhymer JM, Rohwer FC (1992) Philopatry, dispersal, and the genetic structure of waterfowl populations. In: Batt BDJ, Afton AD, Anderson MG, Ankney CD, Johnson DH, Kadlec JA, Krapu GL (eds) Ecology and management of breeding waterfowl. University of Minnesota Press, Minneapolis, pp 365-395

Bellebaum J, Mädlow W (2015) Survival explains sex ratio in an introduced Mandarin Duck Aix galericulata population. Ardea 103:183-187

Bellrose FC, Scott TG, Hawkins AS, Low JB (1961) Sex ratios and age ratios in North American ducks. Ill Nat Hist Surv Bull 27:391-474

BirdLife International 2018. IUCN Red List for birds. http://www.birdl ife.org. Accessed 30 Nov 2018

Blums P, Nichols JD, Hines JE, Mednis A (2002) Sources of variation in survival and breeding site fidelity in three species of European ducks. J Anim Ecol 71:438-450 
Blums P, Nichols JD, Lindberg MS, Hines JE, Mednis A (2003) Factors affecting breeding dispersal of European ducks on Engure Marsh, Latvia. J Anim Ecol 72:292-307

Blums P, Nichols JD, Hines JE, Lindberg MS, Mednis A (2005) Individual quality, survival variation and patterns of phenotypic selection on body condition and timing of nesting in birds. Oecologia 143:365-376

Brides K, Wood KA, Hearn RD, Fijen TPM (2017) Changes in the sex ratio of the Common Pochard Aythya ferina in Europe and North Africa. Wildfowl 67:100-112

Carbone C, Owen M (1995) Differential migration of the sexes of Pochard Aythya ferina: results from a European survey. Wildfowl 46:99-108

Choudhury S, Black JM (1991) Testing the behavioural dominance and dispersal hypothesis in Pochard. Ornis Scand 22:155-159

Christensen TK, Fox AD (2014) Changes in age and sex ratios amongst samples of hunter-shot wings from common duck species in Denmark 1982-2010. Eur J Wildl Res 60:303-312

Devineau O, Guillemain M, Johnson AR, Lebreton J-D (2010) A comparison of green-winged teal Anas crecca survival and harvest between Europe and North America. Wildl Biol 16:12-24

Donald PF (2007) Adult sex ratios in wild bird populations. Ibis 149:671-692

Drever MC, Clark RG (2007) Spring temperature, clutch initiation date and duck nest success: a test of the mismatch hypothesis. J Anim Ecol 76:139-148

Drever MC, Clark RG, Derksen C, Slattery SM, Toose P, Nudds TD (2012) Population vulnerability to climate change linked to timing of breeding in boreal ducks. Gobal Change Biol 18:480-492

Engen S, Lande R, Sæther B-E (2003) Demographic stochasticity and Allee effects in populations with two sexes. Ecology 84:2378-2386

Folliot B, Guillemain M, Champagnon J, Caizergues A (2018) Patterns of spatial distribution and migration phenology of common pochards Aythya ferina in the Western Palearctic: a ring-recoveries analysis. Wildl Biol 2018:wlb.00427

Fox AD, Christensen TK (2018) Could falling female sex ratios among first-winter northwest European duck populations contribute to skewed adult sex ratios and overall population declines? Ibis 160:929-935

Fox AD, Caizergues A, Banik MV, Devos K, Dvorak M, Ellermaa M, Folliot B, Green AJ, Grüneberg C, Guillemain M, Håland A, Hornman M, Keller V, Koshelev AI, Kostyushin VA, Kozulin A, Ławicki Ł, Luigujõe L, Müller M, Muzil P, Musilová Z, Nilsson L, Mischenko A, Pöysä H, Śćiban M, Sjeničič J, Stīpniece A, Švažas S, Wahl J (2016) Recent changes in the abundance of breeding Common Pochard Aythya ferina in Europe. Wildfowl 66:22-40

Frew RT, Brides K, Clare T, Maclean L, Rigby D, Tomlinson CG, Wood KA (2018) Temporal changes in the sex ratio of the Common Pochard Aythya ferina compared to four other duck species at Martin Mere, Lancaster, UK. Wildfowl 68:140-154

Gourlay-Larour M-L, Schricke V, Sorin C, L'hostis M, Caizergues A (2012) Movements of wintering diving ducks: new insights from nasal saddled individuals. Bird Study 59:266-278

Gourlay-Larour M-L, Pradel R, Guillemain M, Santin-Janin H, L'hostis M, Caizergues A (2013a) Individual turnover in Common Pochards wintering in western France. J Wildl Manage 77:477-485

Gourlay-Larour M-L, Pradel R, Guillemain M, Guitton J-S, L'Hostis M, Hugues S-J, Caizergues A (2013b) Movement patterns in a partial migrant: a multi-event capture-recapture approach. PLOS ONE 9(5):e96478

Green RE, Pain DJ (2016) Possible effects of ingested lead gunshot on populations of ducks wintering in the UK. Ibis 158:699-710
Guillemain M, Aubry P, Folliot B, Caizergues A (2016) Duck hunting bag estimates for the 2013/14 season in France. Wildfowl 66:126-141

Helle E, Kauhala K (1991) Distribution history and present status of the raccoon dog in Finland. Holarct Ecol 14:278-286

Hellmann G (1918) On severe winters. Mon Weather Rev 46:330

Hildén O (1964) Ecology of duck populations in the island group of Valassaaret, Gulf of Bothnia. Ann Zool Fenn 1:153-279

Hirschfeld A, Heyd A (2005) Mortality of migratory birds caused by hunting in Europe: bag statistics and proposals for the conservation of birds and animal welfare. Ber Vogelschutz 42:47-74

Hyytiä K, Kellomäki E, Koistinen J (eds) (1983) Suomen Lintuatlas. Suomen Lintutieteellinen Yhdistys, Lintutieto Oy, Helsinki

Kauhala K (1996) Minkki. In: Lindén H, Hario M, Wikman M (eds) Riistan jäljille. Riista- ja kalatalouden tutkimuslaitos. Edita, Helsinki, pp 72-75

Kauppinen J (1983) Methods used in the census of breeding ducks in northern Savo (Finland) at the beginning of the breeding season. Finn Game Res 40:49-81

Keller I, Korner-Nievergelt F, Jenni L (2009) Within-winter movements: a common phenomenon in the Common Pochard Aythya ferina. J Ornithol 150:483-494

Klein Tank AMG, Wijngaard J, Können GP, Böhm R, Demarée G, Gocheva A, Mileta M, Pashiardis S, Hejkrlik L, Kern-Hansen C, Heino R, Bessemoulin P, Müller-Westermeier G, Tzanakou M, Szalai S, Pálsdóttir T, Fitzgerald D, Rubin S, Capaldo M, Maugeri M, Leitass A, Bukantis A, Aberfeld R, van Engelen AFV, Forland E, Mietus M, Coelho F, Mares C, Razuvaev V, Nieplova E, Cegnar T, Antonio López J, Dahlström B, Moberg A, Kirchhofer W, Ceylan A, Pachaliuk O, Alexander LV, Petrovic P (2002) Daily dataset of 20th-century surface air temperature and precipitation series for the European Climate Assessment. Int J Climatol 22:1441-1453

Lee AM, Sæther B-E, Engen S (2011) Demographic stochasticity, Allee effects, and extinction: the influence of mating system and sex ratio. Am Nat 177:301-313

Lehikoinen A, Öst M, Hollmén T, Kilpi M (2008) Does sex-specific duckling mortality contribute to male bias in adult common eiders? Condor 110:574-578

Lehikoinen A, Jaatinen K, Vähätalo AV, Clausen P, Crowe O, Deceuninck B, Hearn R, Holt CA, Hornman M, Keller V, Nilsson L, Langendoen D, Tománkova I, Wahl J, Fox AD (2013) Rapid climate driven shifts in wintering distributions of three common waterbird species. Glob Change Biol 19:2071-2208

Lehikoinen A, Rintala J, Lammi E, Pöysä H (2016) Habitat-specific population trajectories in boreal waterbirds: alarming trends and bioindicators for wetlands. Anim Conserv 19:88-95

Lehikoinen A, Jukarainen A, Mikkola-Roos M, Below A, Lehtiniemi T, Pessa J, Rajasärkkä A, Rintala J, Rusanen P, Sirkiä P, Tiainen J, Valkama J (2019) Linnut. In: Hyvärinen E, Juslén A, Kemppainen E, Uddström A, Liukko U-M (eds) Suomen lajien uhanalaisuus-Punainen kirja 2019. Ympäristöministeriö \& Suomen ympäristökeskus, Helsinki, pp 560-570

Linkola P (1959) Zur Methodik der quantitativen Vogelforschung in den Binnengewässern. Ornis Fenn 36:66-78

Linkola P (1960) Über das Geschlechtsverhältnis bei den Entenvögeln. Ornis Fenn 37:36-45

Mateo R (2009) Lead poisoning in wild birds in Europe and the regulations adopted by different countries. In: Watson RT, Fuller M, Pokras M, Hunt WG (eds) Ingestion of lead from spent ammunition: implications for wildlife and human. The Peregrine Fund, Boise, pp 1-28

McKinney F, Derrickson SR, Mineau P (1983) Forced copulation in waterfowl. Behaviour 86:250-294

Nichols JD, Haramis GM (1980) Sex-specific differences in winter distribution patterns of canvasbacks. Condor 82:406-416 
Nilsson L (1970) Local and seasonal variation in sex-ratios of diving ducks in South Sweden during the non-breeding season. Ornis Scand 1:115-128

Oring LW, Sayler RD (1992) The mating systems of waterfowl. In: Batt BDJ, Afton AD, Anderson MG, Ankney CD, Johnson DH, Kadlec JA, Krapu GL (eds) Ecology and management of breeding waterfowl. University of Minnesota Press, Minneapolis, pp 190-213

Owen M, Dix M (1986) Sex ratios in some common British wintering ducks. Wildfowl 37:104-112

Pöysä H (1996) Population estimates and the timing of waterfowl censuses. Ornis Fenn 73:60-68

Pöysä H, Rintala J, Lehikoinen A, Väisänen RA (2013) The importance of hunting pressure, habitat preference and life history for population trends of breeding waterbirds in Finland. Eur J Wildl Res 59:245-256

Pöysä H, Lammi E, Pöysä S, Väänänen V-M (2019) Collapse of a protector species drives secondary endangerment in waterbird communities. Biol Conserv 230:75-81

Ramula S, Öst M, Lindén A, Karell P, Kilpi M (2018) Increased male bias in eider ducks can be explained by sex-specific survival of prime-age breeders. PLOS ONE 13(4):e0195414

R Core Team (2017) R: a language and environment for statistical compution. R Foundation for Statistical Computing, Vienna. https ://www.R-project.org/
Ridgill SC, Fox AD (1990) Cold weather movements of waterfowl in Western Europe. Special publication 13. International Waterfowl and Wetlands Research Bureau, Slimbridge

Saurola P, Valkama J, Velmala W (2013) The finnish bird ringing atlas, vol 1. Finnish Museum of Natural History and Ministry of Environment, Helsinki

Suter W, van Eerden MR (1992) Simultaneous mass starvation of wintering diving ducks in Switzerland and the Netherlands: a wrong decision in the right strategy? Ardea 80:229-242

Székely T, Liker A, Freckleton RP, Fichtel C, Kappeler PM (2014) Sex-biased survival predicts adult sex ratio variation in wild birds. Proc R Soc B 281:20140342

Valkama J, Vepsäläinen V, Lehikoinen A (2011) Suomen III Lintuatlas. Luonnontieteellinen keskusmuseo ja ympäristöministeriö. http:// atlas3.lintuatlas.fi. Accessed 30 Nov 2018

Vīksne J, Janus M, Mednis A (2011) Factors influencing the number of breeding water birds in Lake Engure, Latvia. Proc Latv Acad Sci Sec B 65:127-137

Publisher's Note Springer Nature remains neutral with regard to jurisdictional claims in published maps and institutional affiliations. 